\title{
Exploring the role of sex steroids through studies of receptor deficient mice
}

Abstract Decades of study have described a number roles fulfilled by the steroid hormones and their respective receptors in sexual differentiation and development, reproductive function and behavior, and more recently in the function and maintenance of non-reproductive organ systems, such

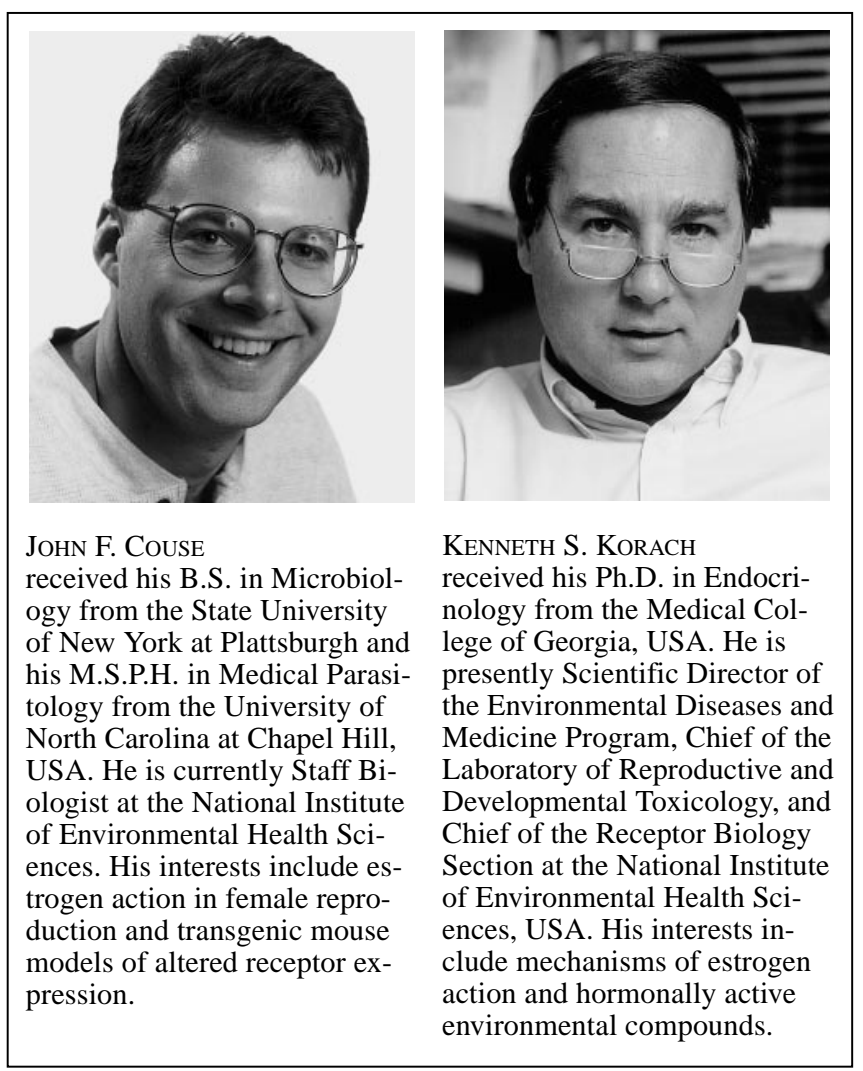

Communicated by: Ulrike Fuhrman and Günter Stock

J.F. Couse $\cdot$ K.S. Korach ( $)$

Receptor Biology Section,

Laboratory of Reproductive and Developmental Toxicology,

National Institute of Environmental Health Sciences,

National Institutes of Health, MD B3-02, P.O. Box 12233,

Research Triangle Park, NC 27709, USA as skeletal muscle, bone and coronary tissues. The biological effects of the steroid hormones are believed to be mediated in part by specific receptor proteins that demonstrated great specificity for their respective steroid ligands. Much of the experimental research of the functions of the sex steroid receptors has depended upon in vitro systems as well as in vivo methods that require surgical castration or the pharmacological administration of hormone antagonists. However, recently developed techniques that allow for manipulation of the mouse genome have been utilized to generate transgenic animals that lack functional estrogen or progesterone receptors. These transgenic animals, combined with the naturally existing Tfm mice which lack functional androgen receptor, now provide in vivo models for further study of the various actions of the sex steroids and their receptors. This review attempts to describe and compare the various phenotypes that result in each of these lines of mice, with emphasis on the development and function of the reproductive systems as well as reproductive behavior.

Key words Androgen receptor - Estrogen receptor . Gonads · Infertility · Mammary gland .

Progesterone receptor $\cdot$ Sexual Behavior

Abbreviations AIS Androgen insensitivity syndrome $A R$ Androgen receptor - cAIS Complete androgen insensitivity syndrome $\cdot D E S$ Diethylstilbestrol ·

$D H T$ 5 $\alpha$-Dihydrotestosterone $\cdot E G F$ Epidermal growth factor $\cdot E R$ Estrogen receptor $\cdot F S H$ Follicle-stimulating hormone $\cdot L H$ Luteinizing hormone $\cdot p A I S$ Partial androgen insensitivity syndrome $\cdot P R$ Progesterone receptor $\cdot T f m$ Testicular feminized male

\section{Introduction}

Over 40 years ago Jost employed a series of classical organ ablation studies to show that fetal gonadectomy of mammalian males and females results in both sexes developing as phenotypic females, thereby demonstrating the importance of gonadal factors in the process of sexual dif- 
ferentiation [1,2]. Since this pioneering work, additional experiments have shown the female to be the constitutive sex of the mammal, and the male the result of secretion of the steroid hormone testosterone as well as the peptide antimüllerian hormone by the fetal testes [3]. In addition, testicular hormones are known to be critical to the determination of sex differences in brain and behavior $[4,5]$. Although hormonal secretions from the fetal ovary do not seem to be required for proper prenatal development of the female reproductive tract, a vast literature describes the teratogenic and carcinogenic effects of developmental exposure to exogenous estrogens in the reproductive tract and brain of both females and males [6-10]. In fact a recent study has shown that excess levels of estradiol in the placenta results in midgestational death in the mouse [11]. The broad indication of these and several contributing studies is the dependence of fetal tissues on the sex steroid hormones, as well as the fact that these same hormones can be deleterious when present at aberrant times or in abnormal amounts.

The biological effects of the steroid hormones are believed to be mediated in part by specific receptor proteins that demonstrate great specificity and high affinity for their respective steroid ligands under normal physiological conditions. The estrogen receptor (ER), androgen receptor (AR), and progesterone receptor (PR) are all class I members of the nuclear receptor superfamily as defined by Mangelsdorf et al. [12]. These receptors are characterized as ligand-inducible transcription factors composed of a highly conserved modular structure of functional domains termed $\mathrm{A}-\mathrm{F}$, with the $\mathrm{C}$ domain responsible for binding to specific DNA sequence elements, and the $\mathrm{E}$ domain responsible primarily for ligand binding. Also included within the receptor are regions involved in nuclear localization, dimerization, and transcriptional activation. The inactive receptor is in the form of a large complex made up of loosely bound heat-shock and other accessory proteins. Upon binding of ligand the receptor is activated and released, thereby allowing the receptor-ligand complexes to form homodimers, which bind to DNA half-sites organized as inverted repeats in the regulatory regions of target genes (as reviewed by Freedman in this volume), resulting in transcription/translation of specific gene products and ultimately a cellular or tissue response.

A target tissue for a steroid hormone has been traditionally defined as one possessing functional levels of the respective receptor protein as well as a measurable response when exposed to the hormone. Several studies have demonstrated the presence of ER, AR, and PR in various tissues of the undifferentiated and developing fetal reproductive tract, as well as in the fetal brain and pituitary of mammals (reviewed in [13]). In the adult, several tissues of the reproductive tract and brain of both sexes as well as several nonreproductive tissues maintain detectable levels of the steroid hormone receptors. Decades of study have described a plethora of roles fulfilled by the steroid hormones and their respective receptors in sexual differentiation and development, in reproductive function and behavior, and more recently in the function and maintenance of nonreproductive organ systems such as the skeletal muscle, bone, and coronary tissues. These conclusions are inferred from data of a combination of several in vitro and in vivo experimental schemes as well as from studies of the testicular feminized male (Tfm) mouse and rat, which possesses a naturally occurring mutation that results in the lack of functional AR. However, recently developed techniques that allow for manipulations of the mouse genome have been utilized to generate transgenic animals that also lack either ER or PR. To date, studies on these transgenic mice have confirmed, as well as contrasted, several of the previous conclusions concerning the role of these sex steroids and more importantly now provide a tool for further study of the various actions of these hormones and their receptors. This review discusses the generation of the ER knock-out (ERKO) mouse, the PR mutant mouse, and the naturally occurring Tfm mouse and the subsequent phenotypes of each, with emphasis on the reproductive tract, hypothalamic-pituitary-gonadal axis, the mammary gland, and sexual behavior.

\section{The sex steroid receptor deficient mice}

\section{The Tfm mouse (androgen receptor mutation)}

The AR is a $110-\mathrm{kDa}$ protein that binds and mediates the biological effects of the steroid hormone testosterone and its more potent metabolite $5 \alpha$-dihydrotestosterone (DHT), both having overlapping yet distinct roles in the overall functions of the androgen signaling system. In contrast to the other sex steroid receptors, a human syndrome of androgen insensitivity due to the lack of functional AR has been well described (reviewed in [14]). Androgen insensitivity syndrome (AIS) is an X-linked, heritable trait resulting from mutations in the AR gene. In the human, several different mutations of the AR gene have been documented, all leading to androgen insensitivity that is either complete (cAIS) or partial (pAIS). These include amino acid substitutions in the DNA or ligand binding domains resulting in abnormal receptor function, point mutations that introduce a premature stop codon or result in aberrant splicing of the AR mRNA, or deletions of part of or the entire AR gene (reviewed in [15]). The murine equivalent of human cAIS was first described in 1970 and named the Tfm mouse [16], which possesses a single point mutation in the N-terminal region of the AR gene that results in a premature stop codon [17], resulting in the expression of detectable levels of a nonfunctional, truncated form of the AR [18]. The lack of androgen action results in complete infertility in the Tfm mouse, and furthermore, because the trait is Xlinked, all androgen-insensitive mice are genetically male. Therefore it is impossible to generate a genetically female mouse that is homozygous for the AR gene mutation via conventional breeding methods. However, by breeding Tfm carrier females with males that were chimeric for the AR gene mutation, Lyon and Glenister [19] were able to generate a small number of homozygous Tfm female mice. 
The estrogen receptor- $\alpha$ knockout mouse

The ER is a $66-\mathrm{kDa}$ protein that binds and mediates the effects of the natural estrogen $17 \beta$-estradiol. In contrast to the receptor-based insensitivity syndromes to androgen as well as thyroid hormones [20], there had been no reported mutations in the ER of normal tissue that result in estrogen insensitivity in humans or laboratory animals. This encouraged investigators to believe that a functional estrogen signaling system was critical to survival, and that any disruption of this pathway would prove lethal during the very early developmental stages. Therefore the effects of estrogen insensitivity during development as well as adulthood could be evaluated only with studies utilizing gonadectomy and/or antiestrogen compounds in in vitro and in vivo experimental systems. However, with the advances in the field of gene targeting via homologous recombination in mouse embryonic stem cells, it was possible to attempt to generate a transgenic mouse line that would be homozygous for a disruption of the ER gene. If the gene disruption did prove lethal, a model to study the precise time and locations of receptor-mediated estrogen actions during development would be available. However, providing the animal was viable, an in vivo model of estrogen insensitivity would now be available for study.

The targeting scheme utilized to disrupt the mouse ER gene has been described in detail [21] and will not be repeated in this review. Surprisingly, our efforts led to the generation of mice of both sexes that are homozygous for the ER gene disruption (termed ERKOs) [21]. The distribution of the three possible ER genotypes (wild-type, heterozygous, and ERKO) in the litter of a heterozygous breeding pair followed the expected Mendelian distribution, indicating no lethal effects of the gene disruption [21]. Furthermore, both male and female mice were equally represented, indicating no bias toward either sex and therefore no apparent effect on sexual differentiation in the mouse. ERKO mice of both sexes survive to adulthood and develop grossly normal external genitalia but are infertile [21]. Soon after the generation of the ERKO mice came the first description of a human case of estrogen resistance, in which an adult male was found to be homozygous for a point mutation resulting in a premature stop codon in the ER gene [22].

Until recently only a single type of ER able to mediate the hormonal effects of estradiol in the normal physiological processes of the mammal was thought to exist. However, the recent descriptions of a separate gene encoding a second type of ER, termed ER $\beta$, in the rat [23], mouse [24], and human [25] has prompted a reexamination of the estrogen signaling system. When compared to the classical ER (now referred to as $\mathrm{ER} \alpha$ ), the protein sequence of the mouse ER $\beta$ demonstrates considerable homology in the DNA and ligand-binding domains [24]. Relative binding studies on in vitro translated protein have shown that the $\operatorname{ER} \beta$ is able to bind $17 \beta$-estradiol with an affinity similar to that of $\operatorname{ER} \alpha[23,24]$. Transactivation studies utilizing an estrogen-responsive reporter construct transfected into mammalian cell lines have shown that the ER $\beta$ is able to mediate the effects of $17 \beta$-estradiol in a dose-dependent manner, and that this activity can be significantly reduced by the addition of the known ER $\alpha$ antagonists, hydroxytamoxifen [23, 24], ICI-182780, raloxifene [24], and ICI-164384 [25]. With the discovery of a second type of ER, it is important to redefine the ERKO mice as being homozygous for a disruption of the ER $\alpha$ gene only and therefore still possessing a functional ER $\beta$ gene. We have recently shown that the distribution pattern and levels of $\mathrm{ER} \beta$ mRNA in several tissues of the ERKO mouse do not appear to differ from their wild-type counterparts [26]. Therefore the interpretation of phenotypes and experimental findings from the ERKO mice must account for the presumably intact functions of the ER $\beta$.

\section{The progesterone receptor mutant mouse}

Progesterone has been traditionally defined as the "pregnancy hormone" in the mammal and is central to the coordinated development of the preimplantation embryo and the maternal uterus, ultimately leading to the establishment and maintenance of pregnancy [27]. The PR exists in two naturally occurring isoforms, termed $\mathrm{PR}_{\mathrm{A}}(94 \mathrm{kDa})$ and $\mathrm{PR}_{\mathrm{B}}(116 \mathrm{kDa})$, that arise from the same gene (reviewed in [28]). The PR is known to be present in the uterus, ovary, mammary gland, and brain. In most progesterone target tissues the PR gene is up-regulated by estrogen acting via ER [29]. Therefore many of the observed physiological responses to progesterone may actually be due to the combined effects of both progesterone and estrogen acting via their respective receptors. In an attempt to generate an in vivo model to discern the roles of the progesterone/PR and estrogen/ER signaling systems as well as to provide a model for the direct study of PR function, O'Malley and colleagues [30] have utilized homologous recombination in mouse embryonic stem cells to generate a line of transgenic mice that are homozygous for a disruption of the PR gene. As in the ERKO, heterozygous breeding pairs resulted in a Mendelian distribution of genotypes and equal representation of sexes, indicating no effect of the loss of PR on viability nor sexual differentiation [30, 31]. Females homozygous for the PR gene disruption are completely infertile while no apparent effects on male fertility have been revealed to date.

\section{Reproductive phenotypes in female mice}

\section{The uterus}

The mammalian uterus arises from the differentiation of the müllerian ducts in the absence of the testicular secretions testosterone and antimüllerian hormone during fetal development [3]. The developing uterus is known to possess the receptors for all three sex steroid hormones during development, initially in the mesenchyma and later in the 
epithelium [13]. Prenatal development of the female reproductive tract is not dependent on ovarian factors, therefore it was not surprising that the uteri of females of both the ERKO and the PR mutant mice develop normally [21,30]. However, in the adult the specialized tissues of the uterus as well as the whole female reproductive tract are known to undergo continuous synchronized phases of proliferation and differentiation under the influence of ovarian estrogen and progesterone. Therefore disruption of the genes for the ER $\alpha$ and PR was expected to result in a uterus that is completely unresponsive to their respective hormones and therefore unable to function normally.

The uteri of adult ERKO female mice possess all the characteristic tissue compartments, these being the myometrium, stroma, and epithelium, but are hypoplastic and weigh approximately half that of their wild-type littermates. The response of the rodent uterus to estradiol has been well described and is known to occur in distinct phases, with initial increases in water imbibition, vascular permeability, hyperemia, prostaglandin release, and protein synthesis [32]. This is then followed by dramatic increases in DNA synthesis, cellular proliferation, and hypertrophy within $24 \mathrm{~h}$ of exposure [33]. The lack of a full uterotropic response to estrogen in the adult female ERKO has been described [21, 34]. In brief, when ovariectomized mice were treated with $40 \mu \mathrm{g} 17 \beta$-estradiol $/ \mathrm{kg}$ body weight for 3 consecutive days, wild-type mice showed the expected three- to fourfold increase in uterine wet weight whereas no response was observed in the uteri of ERKO mice [21]. These same results were obtained when similar mice were treated with the potent estrogen diethylstilbestrol (DES) $(40 \mu \mathrm{g} / \mathrm{kg})$ [35] or hydroxytamoxifen $(1 \mathrm{mg} / \mathrm{kg})$, an estrogen agonist in the mouse uterus [34]. The dependency on the presence of ER $\alpha$ for proper uterine cellular proliferation after estrogen exposure was confirmed by a $[3 \mathrm{H}]$ thymidine incorporation assay in which no significant increase in DNA synthesis over control animals was observed in the ERKO, compared to a tenfold increase in the wild-type after a single estrogen treatment [36].

In addition to the lack of mitogenic actions of estradiol in the uteri of ERKO mice, further studies have also shown resistance in the regulation of known estrogen-induced genes. The regulatory regions of both the mouse PR [29] and lactoferrin [37] genes have been shown to possess estrogen/ER $\alpha$ regulatory sequences that result in the up-regulation of each in response to estradiol. Therefore PR and lactoferrin regulation in the uterus after estrogen exposure has often been used to attest for the presence of functional $\mathrm{ER} \alpha$ or for the estrogenic activity of an experimental compound. In the ERKO mouse, neither gene is up-regulated $24 \mathrm{~h}$ after treatment with $17 \beta$-estradiol, confirming the need for functional ER $\alpha$ in this response [36]. However, detectable basal levels of PR mRNA are found in ERKO uteri when assayed by northern blot analysis, indicating both an ER $\alpha$-dependent and an ER $\alpha$-independent regulation of this gene [36].

In recent years several studies have indicated a role for polypeptide growth factors, such as epidermal growth factor (EGF), as mediators of estrogen-induced mitogenesis in the rodent uterus. This hypothesis is based on experiments demonstrating that estradiol up-regulates the uterine expression of both EGF and its receptor [32,38], and that treatment of mice with EGF mimics the effects of estradiol in terms of increased DNA synthesis, modified cell morphology, and lactoferrin expression in the uterus [39]. Further studies showed that treatment with an anti-EGF antibody is able to attenuate the uterine response to estradiol [39], and that treatment with the estrogen antagonist ICI164384 is able to attenuate the uterine response to EGF [40]. The culmination of these and several other studies has led to a model in which the mitogenic actions of estradiol in the rodent uterus appear to be at least partially mediated by EGF; however, in turn the mitogenic effects of EGF require the presence of ER $\alpha$. Therefore the ERKO female mouse provided an excellent in vivo model to study the cross-talk between the ER $\alpha$ and EGF signaling systems in the uterus. We have recently shown that although the ERKO uterus possesses normal levels of functional EGF and its receptor, it is unresponsive to the mitogenic actions of EGF, confirming the interaction between these two signaling systems [41]. However, not all EGF responses are negated in the uteri of ERKO females, as this same study demonstrated that the mechanisms for EGF mediate up-regulation of the c-fos gene remain intact in the ERKO [41].

As mentioned above, the mechanisms of estrogen-induced mitogenesis in the uterus partially involves up-regulation of the PR and its subsequent actions. Therefore full interpretation of the data on the lack of estrogen effects in the ERKO must be considered only in the context that eradication of the ER $\alpha$ signaling pathway may also result in the attenuation of PR functions. The generation of the PR mutant mouse has now provided an in vivo model to fully dissect the roles of each steroid hormone in uterine functions. The studies described below are discussed in greater detail in the initial description of the PR mutant mouse by Lydon et al. [30]. As expected, the uteri of the PR mutant mice developed normally and possessed the normal uterine architecture. When ovariectomized adult wild-type and PR mutant animals were treated with daily injections of estradiol $(1 \mu \mathrm{g} / \mathrm{kg})$ and progesterone $(1 \mathrm{mg} / \mathrm{kg})$ for 3 weeks, the wild-type responded with the characteristic enlarged, fluid-filled, and "highly developed" uterus, whereas the uteri of the PR mutant were abnormally large, indicative of a hyperestrogenic response [30]. Histological analysis of the uteri from treated PR mutant mice indicated extracellular edema resulting in a thickened uterine wall, extensive proliferation of the glandular epithelia, an acute inflammatory response in the mucosa, submucosa, and stromal components of the endometrium, and an overall hyperplastic and disorganized epithelium compared to treated wild-type controls [30]. These results are in accordance with earlier studies of ovariectomized female mice after chronic treatments with estrogen alone [42]. Furthermore, these experiments in combination with those described above in the ERKO confirmed the definitive role of the estrogen/ER $\alpha$ signaling pathway in the proliferative functions of the uterus. 
The inflammatory response in the uteri of the PR mutant mice after the estrogen/progesterone treatment was extensive, consisting of "marked" infiltration of polymorphonuclear leukocytes in the endometrial stroma and mucosal epithelium as well as in the uterine luminal fluid [30]. A series of in vitro studies have shown progesterone to be inhibitory to the expression of cytokines that are known to be chemotactic to neutrophils and T lymphocytes [43, 44]. Furthermore, the antiprogestin RU486 is known to stimulate prostaglandin E levels in the decidual and chorionic tissue during early pregnancy [45]. These reports along with the experimental evidence obtained from the PR mutant mouse have prompted Lydon et al. $[30,31]$ to suggest that progesterone acting via the PR is necessary to suppress the local inflammatory responses that may accompany implantation of the embryo, thereby fulfilling its role in the establishment and maintenance of pregnancy.

\section{The ovary}

The single study concerning homozygous Tfm female mice concluded that normal levels of AR are not critical to reproductive capabilities in the female [19]. However, compared to wild-type females, the reproductive life span in the Tfm females appeared to be significantly shortened, reportedly due to an accelerated aging process in the ovary [19]. In contrast, the uterine phenotypes in the ERKO and PR mutant mice described above are only a single factor responsible for the infertility of the homozygous mutant females of both transgenic lines. Each model has also provided unique ovarian phenotypes that culminate in the lack of ovulation and therefore may provide the primary explanation for the infertility of the females of each transgenic line.

The adult ERKO ovary is characterized by the presence of primordial, primary, and secondary follicles as well as a consistent absence of ovulatory follicles and corpora lutea. Rather than proceeding through the stages of folliculogenesis to ovulation, the follicles in the ovaries of ERKO mice appear ultimately to become arrested in a preantral stage and eventually become atretic, leading to the characteristic large, hemorrhagic, and cystic structures shown in Fig. 1.

The ERKO ovarian phenotype does not become apparent until after puberty and is therefore thought to be partly due to the abnormal hormonal balance that exists in the adult ERKO. The sexually mature ERKO female possesses tenfold the normal circulating levels of estradiol [36]. Elevated levels of the respective hormone are consistent with other syndromes of steroid hormone receptor based insensitivity, such as in persons with thyroid hormone resistance [20], androgen insensitivity [14], and vitamin D dependent rickets type II [46]. The development of preovulatory follicles and the ovarian secretion of estradiol are closely related and known to be under the regulation of the anterior pituitary gonadotropins, follicle-stimulating hormone (FSH) and luteinizing hormone (LH; reviewed in [47]). However, the mechanisms that regulate the production/secretion of
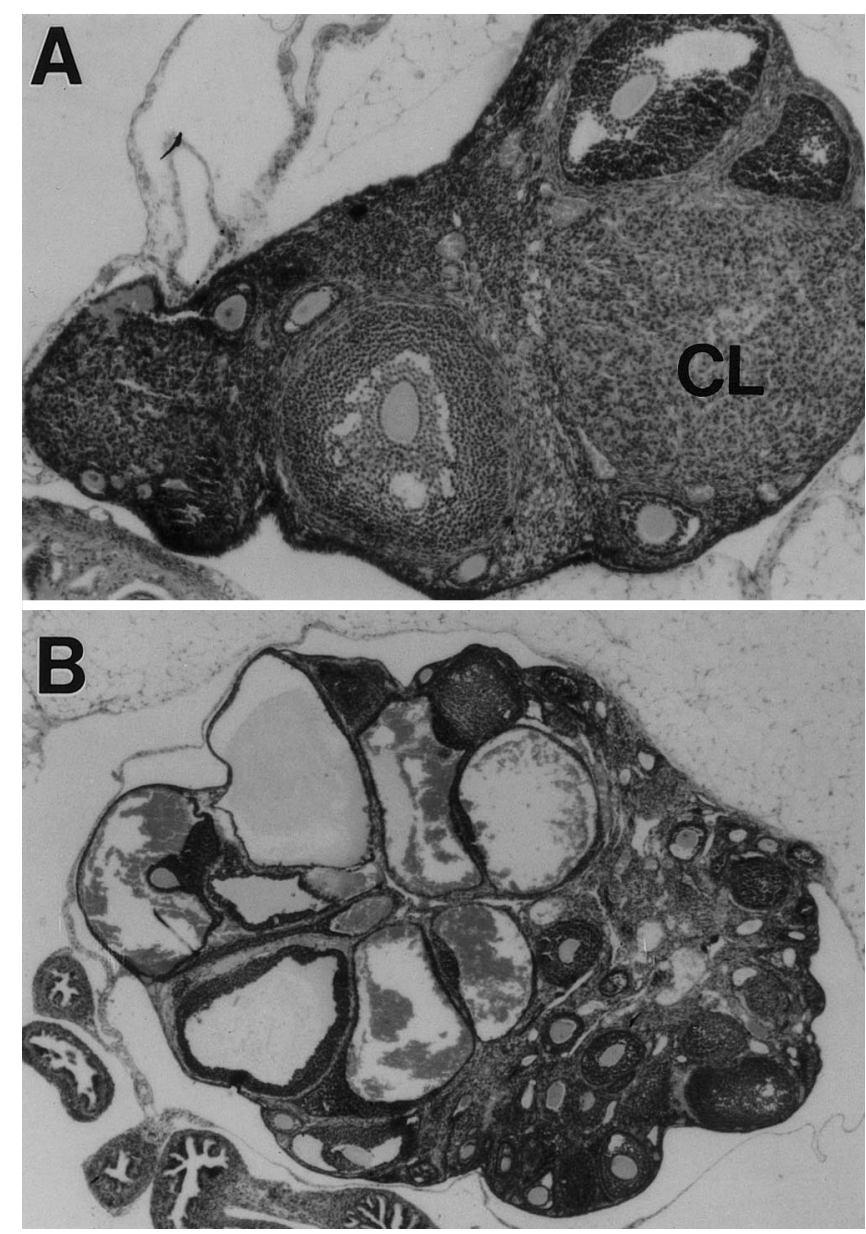

Fig. 1A,B Ovarian phenotype in the adult ERKO female mouse. Shown are histological cross-sections of a typical wild-type (A) and ERKO (B) ovary. The wild-type ovary exhibits the various stages of folliculogenesis, including a prominent corpora lutea $(C L)$. The ERKO ovary is characterized by the presence of primary, secondary, and preantal follicles; however, maturing follicles become arrested and develop into the cystic and hemorrhagic structures shown

the gonadotropins are poorly understood but are considered to be at least partially controlled by the estrogen/ER signaling pathway in the anterior pituitary and hypothalamus. In brief, a simple negative feedback mechanism exists in which increased FSH and LH levels stimulate the process of folliculogenesis and subsequently increased production of estradiol in the ovary. When the estradiol concentration reaches a maximal threshold, its actions are thought to return the circulating FSH and LH levels back to a basal level, either via suppressed secretion of gonadotropin releasing hormone from the hypothalamus and/or direct actions on the gonadotropes in the anterior pituitary (reviewed in [48]). This mechanism is thought to be dependent on the presence of ER $\alpha$ in the hypothalamus and/or gonadotropes of the anterior pituitary, and it was therefore predicted that with a loss of ER $\alpha$ function and thereby ablation of the feedback system, gonadotropin levels in the female ERKO would be significantly elevated. A recent study by Scully et al. [49] has indeed demon- 

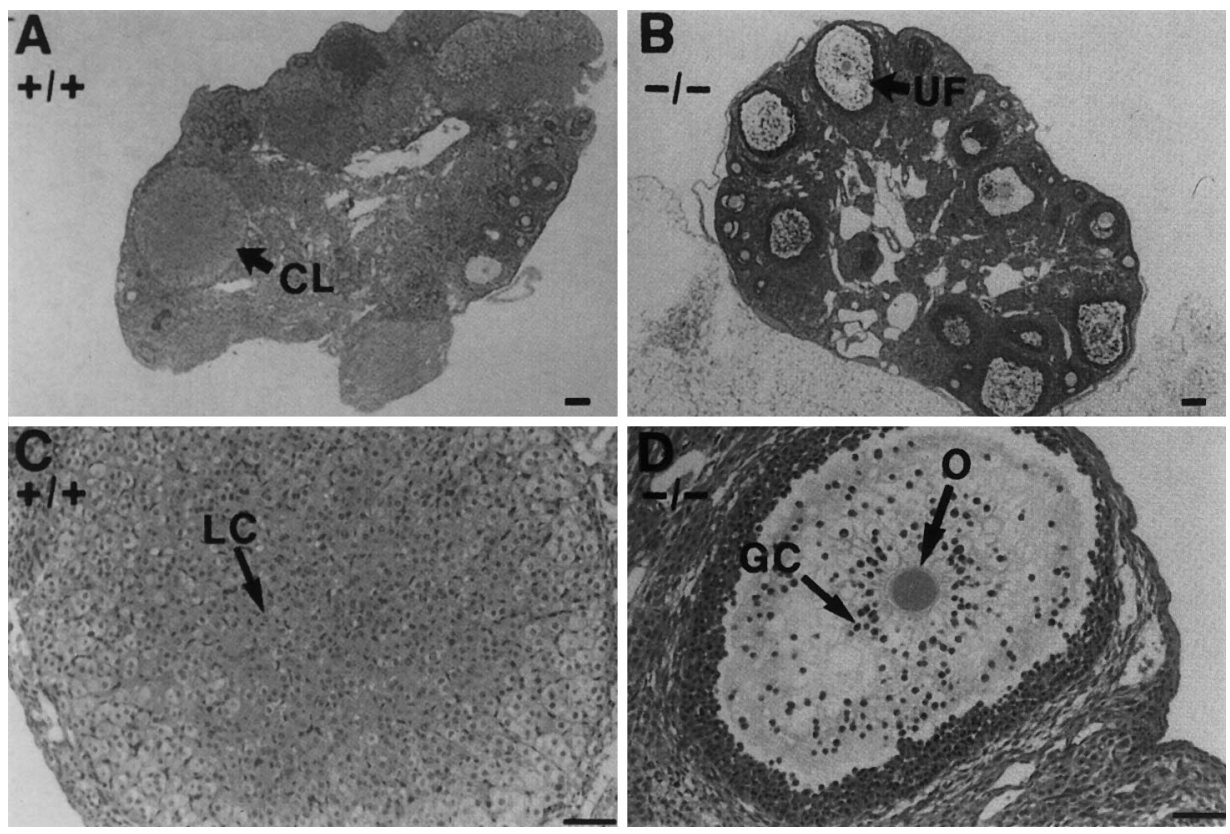

Fig. 2A-D Ovarian response to pregnant mare serum gonadotropin (PMSG) and human chorionic gonadotropin (hCG) treatment in the PR mutant female mouse. A Cross-section of an ovary from a 6week-old wild-type mouse $(+/+)$ treated with an intraperitoneal injection of 5 IU PMSG, followed $48 \mathrm{~h}$ later with 5 IU hCG and killed $24 \mathrm{~h}$ later. Note the presence of numerous corpora lutea $(C L)$. Scale bar, $100 \mu \mathrm{m}$. B Cross-section of an ovary from an age-matched homozygous PR mutant (-/-) female that was hormonally treated exactly as the wild-type described above. Note the unusual presence of several unruptured follicles $(U F)$. Scale bar, $100 \mu \mathrm{m}$. C High-power magnification (20) of a CL present in the wild-type ovary, exhibiting the characteristic hypertrophied luteal cells $(L C)$. Scale bar, $50 \mu \mathrm{m}$. D High-power magnification (20) of a UF present in the PR mutant ovary, exhibiting an intact oocyte $(O)$ with a zona pellucida and granulosa cells $(G C)$ that have undergone cumulus expansion. Note the lack of luteinzation among the GCs compared to those in $\mathbf{C}$. Scale bar, $50 \mu \mathrm{m}$. (With permission from [30])

strated that the levels of the respective mRNAs encoding the common gonadotropin subunit, $\alpha$-glycoprotein subunit, as well as the specific subunits, LH $\beta$ and FSH $\beta$, are significantly up-regulated in the ERKO female, consistent with a syndrome of estrogen resistance. However, only circulating levels of LH are elevated whereas FSH appears to be within the normal range, suggesting a suppressive role for the ER $\alpha$ in LH secretion in the adult female. The possible explanations for the normal serum levels of FSH are under investigation, including studies to determine the circulating levels of inhibin, an ovarian hormone known to suppress FSH secretion [48].

The ovarian phenotype in the adult ERKO female may be due partly to chronic exposure to LH. Under normal conditions subsequent increases in FSH and LH levels lead to follicular maturation and ultimately to ovulation. However, it is thought that the follicular requirements for $\mathrm{LH}$ are finite, and abnormally high levels terminate normal development and result in atresia [47]. Therefore the atretic and cystic follicles observed in the ovaries of ERKO females are possibly a result of LH levels being above that

which is required. In support of this gonadotropin-based explanation of the ERKO ovarian phenotype is a report in which Risma et al. [50, 51] describe similarly hemorrhagic and cystic follicles in the ovaries of transgenic mice that overexpress the $\mathrm{LH} \beta$ gene.

Although the elevated LH levels in the female ERKO may be a factor, the absence of ER $\alpha$ in the ovarian tissues themselves may also contribute to the ovarian phenotype. Studies in the rat have demonstrated the presence of detectable estradiol binding in the granulosa cells of the ovary [52], suggesting a possible role for para-/autocrine actions of estradiol in the ovary. This is supported by a report of Dukes et al. [53] in which continuous treatment of rats with the antiestrogen ZM189154 resulted in the appearance of ovaries that were similar to those of the adult ERKO. Furthermore, studies in the rat ovary have indicated that estrogen is required to counteract the atretogenic effects of androgens (reviewed in [54]), possibly a significant factor since the circulating levels of testosterone in the adult ERKO female are significantly higher than those of wild-type littermates [55]. Interestingly, among several tissues analyzed by RNase protection assay in the mouse, the ovary possesses the greatest concentration of ER $\beta$ mRNA [26]. In fact transcripts for ER $\beta$ are the predominant species of ER encoding mRNA in the adult wild-type mouse ovary [26]. In situ hybridization studies have localized the ER $\beta$ expression to the granulosa cells of follicles at various stages of folliculogenesis [23, 24]. Therefore it is possible that the high-affinity estradiol binding factor detected by Richards et al. [52] is the product of the ER $\beta$ gene. These data suggest that ER $\beta$ is the major receptor responsible for mediating the actions of estradiol in the ovary. However, despite the presence of relatively normal levels of ER $\beta$ mRNA in the ovaries of adult ERKO mice, the loss of functional ER $\alpha$ results in the characteristic phenotype described above. Therefore it is possible that the actions of ER $\beta$ are directly dependent on the presence of 
Fig. 3A-C Morphological appearance of wild-type and ERKO mammary glands from adult females. Whole-mount preparations of the inguinal mammary gland from ERKO (A) and wild-type (C) females at low-power magnification. Boxes, regions of the field shown under high-power magnification in the ERKO (B) and wild-type (D). Note the rudimentary ductal structure in the ERKO mammary gland compared to the fully developed ductal network that exists in the typical wild-type mammary gland
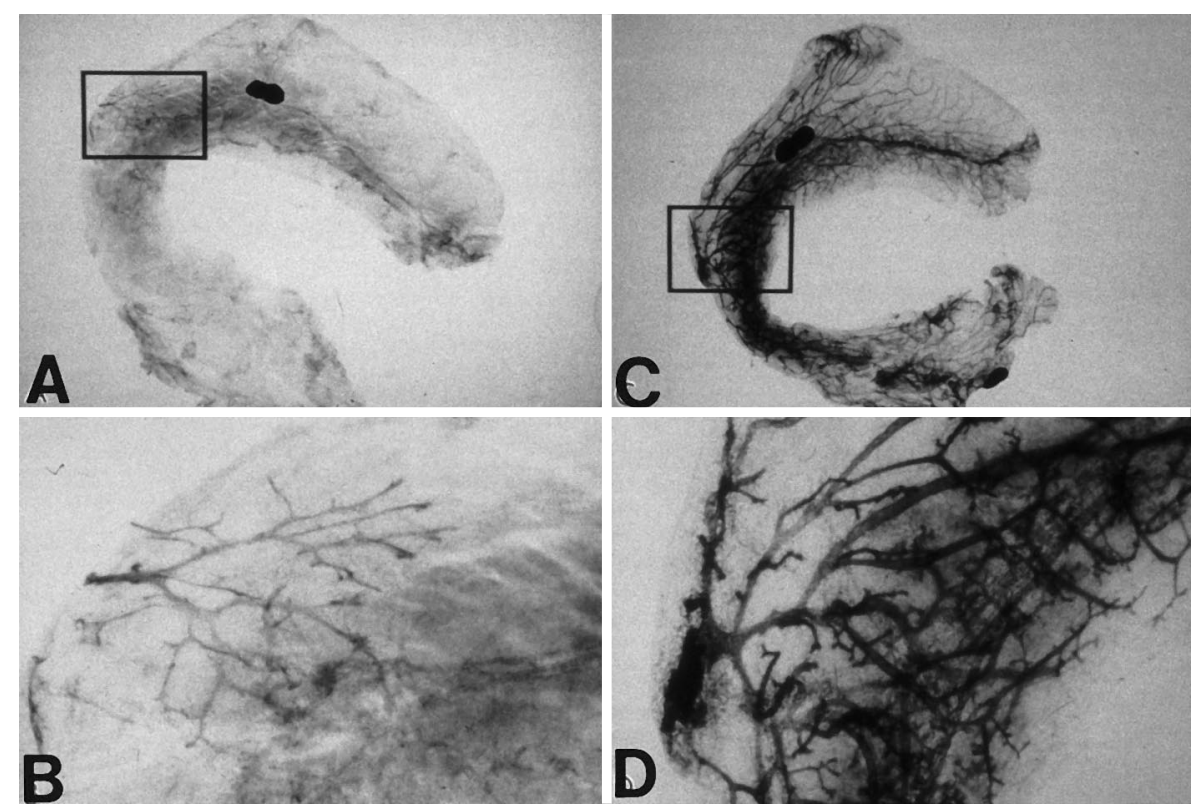

functional $E R \alpha$, or that a critical role for ER $\alpha$ precedes the functions fulfilled by ER $\beta$ during follicular maturation.

Unlike the ovary of adult ERKO females, the ovaries of the PR mutant females are reported to appear normal upon gross and histological evaluation [30]. Nonetheless, PR mutant females are completely infertile when repeatedly mated with wild-type males. An in depth study by Lydon et al. [30] demonstrated that a superovulation treatment regimen with the exogenous gonadotropins, pregnant mare serum gonadotropin and human chorionic gonadotropin, resulted in no oocytes in the oviduct or uterine horn of PR mutant females, compared to an average of more than ten oocytes per animal in similarly treated wild-type mice, indicating a lack of ovulation in the PR mutants. As shown in Fig. 2, the ovaries from superovulated PR mutant females are characterized by the presence of several unruptured preovulatory follicles and the subsequent absence of corpora lutea [30]. These follicles possess an intact mature oocyte that shows no signs of necrosis, and the presence of nonluteinized granulosa cells near the oocyte and basal lamina [30]. These studies have now confirmed a role for progesterone in the process of ovulation, a hypothesis that was suggested by previous studies with inhibitors of progesterone synthesis [56] and the antiprogesterone RU486 [57] as well as in the process of granulosa cell luteinization, as has been previously suggested $[58,59]$.

The overall body of data collected from the ovarian phenotypes in the ERKO and PR mutant mice indicates significant and distinct roles for each steroid hormone and its receptor in the process of oocyte maturation and ovulation. It appears that the actions of the ER $\alpha$ are called upon earlier in the process of folliculogenesis, whereas the PR signaling events are required in the final stages of the ovarian cycle leading up to ovulation and the development of the corpora lutea. Both models should prove invaluable in further dissecting the roles of each steroid hormone in the proper function of the ovary.

\section{The mammary gland}

As in the uterus, the actions of estradiol and progesterone are thought to be critical to the proper functions of the mammary gland. However, the mammary gland is essentially undeveloped at birth in mammals and does not undergo complete growth and differentiation until the onset of puberty, under the influence of both estrogen and progesterone as well as growth hormone (reviewed in [60]). The actions of estrogen and progesterone in the mammary gland have long been assumed to be that of proliferation and differentiation, respectively. In fact, progesterone has also been proposed to play an antiproliferative role in the mammary gland [27]. Once again, the definitive roles of these two steroid hormones in mammary tissue are difficult to segregate because estrogen/ER $\alpha$ action results in the up-regulation of PR levels and therefore increased stimulation of the progesterone signaling pathways as well. Therefore the resulting phenotypes from the ERKO and PR mutant animals have proved useful in investigating the functions of these two steroid hormones.

The mammary gland of an adult wild-type female mouse consists of a network of epithelial ducts originating from the nipple and forming a treelike structure, each branch terminating in the form of an alveolar bud (as shown in Fig. 3). At maturity this ductal structure completely fills the fat pad that makes up the mammary gland. However, the mammary glands of mature ERKO females demonstrate a simple rudimentary branch structure confined to the nipple region (Fig. 3), resembling that of a normal female mouse prior to the onset of puberty. This rudimentary structure is thought to be the result of the ac- 
tions of maternal growth hormone during prenatal development and is likely independent of steroid hormone action.

The lack of mammary gland development in the ERKO is most likely the result of the loss of both direct and indirect actions of estrogen in this tissue. Although the sera of ERKO females possess levels of estradiol that are approximately ten times the norm as well as physiological levels of progesterone [36], no further development of the mammary gland appears with age, indicating resistance to both hormones. Preliminary analysis has shown that the mammary glands of ERKO mice possess slightly detectable levels of PR mRNA but show no up-regulation when treated with estradiol (Bocchinfuso and Korach, unpublished data). Therefore the mouse mammary gland is an excellent example of estrogen resistance also leading to the attenuation of progesterone action. Furthermore, the local actions of peptide growth factors such as EGF and transforming growth factor- $\alpha$ are thought to be critical to proper mammary growth and development, but are also at least partially regulated by estrogen via the ER [61]. Studies to determine whether the underdeveloped ERKO mammary gland can be rescued by exogenous treatment with these growth factors are currently underway. Lastly, the anterior pituitary hormone, prolactin, is also thought to play a role in proper mammary gland development and function, but, once again, estrogen is known to act as a positive regulator of prolactin production and/or secretion [62]. This may be relevant since pituitaries of adult ERKO females have recently been shown to possess prolactin mRNA levels that are nearly 20 -fold lower than that of their wild-type counterparts [49].

As mentioned above, the role of progesterone in mammary tissue has been thought to be mainly in differentiation of the gland, and possibly also playing an antiproliferative role. However, several reports have indicated mitogenic actions of progesterone in mammary tissue, such as an ability to augment the mitogenic response to estrogen when coadministered [60]. The phenotype of the adult PR mutant female has provided evidence to support such a dual role for progesterone [30]. As shown in Fig. 4, the mammary gland of an adult virgin PR mutant female shows no gross difference in overall epithelial ductal development compared to the wild-type [30]. However, when treated with both estrogen and progesterone over a period of 3 weeks, the mammary glands of wild-type mice demonstrated a "complex ductal arborization" throughout the fat pad as well as the expected lobuloalveolar development characteristically associated with pregnancy [30]. The mammary glands of similarly treated PR mutant females revealed a ductal structure with less branching and a complete absence of lobuloalveolar structures at the termini of the branches (Fig. 3) [30]. These experiments led Lydon et al. [30] to conclude that progesterone does indeed play a role in the proliferation of the mammary ductal branching and is critical to the development of the structures required for lactation.

Several conclusions can be drawn to date from comparisons between ERKO and PR mutant mice in terms of mammary gland development. First, initial prepubertal de-
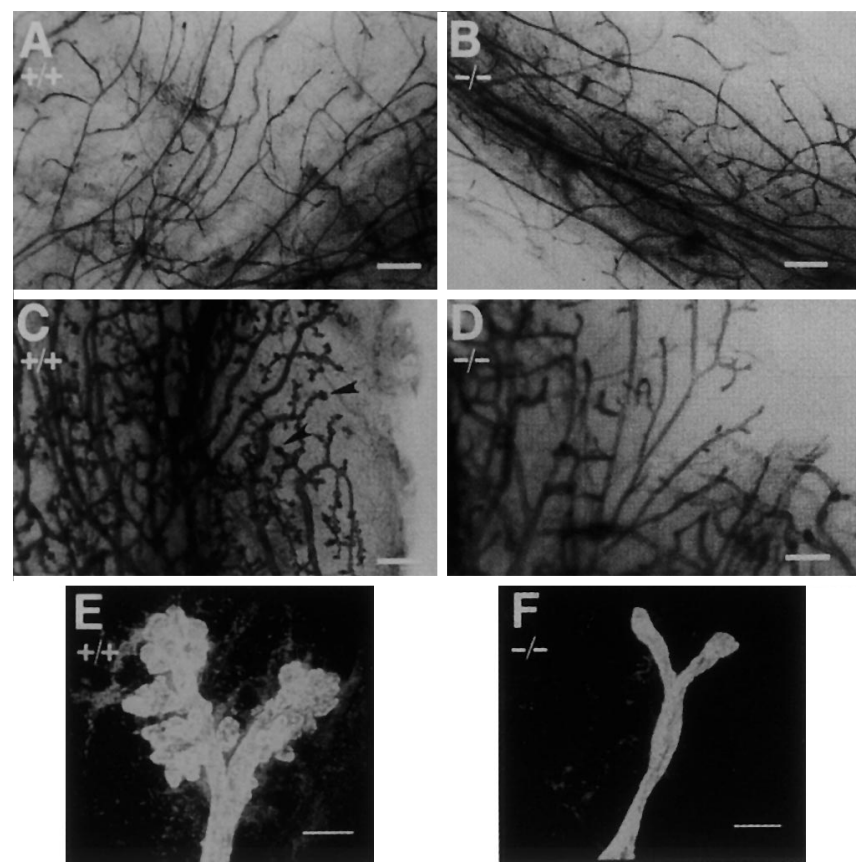

Fig. 4A-F Morphological appearance of wild-type and PR mutant mammary glands with or without estrogen and progesterone treatment. Whole mount preparations of the inguinal mammary glands of ovariectomized hormonally untreated 6-week-old wild-type (A) and PR mutant (B) females. Scale bar, $500 \mu \mathrm{m}$. Whole-mount preparations of the inguinal mammary glands of ovariectomized, progesterone-, and estrogen-treated wild-type (C) and PR mutant (D) female. Hormone treatments consisted of daily subcutaneous injections of $1 \mu \mathrm{g} 17 \beta$-estradiol and $1 \mathrm{mg}$ progesterone for 3 weeks. Arrows, terminal end buds in the wild-type hormonally treated mammary gland whole mount $(\mathbf{C})$. Note the absence of terminal end buds and the presence of less extensively branched ductal structure in the PR mutant mammary gland (D). Scale bar, $500 \mu \mathrm{m}$. Confocal microscopy of the terminal end bud of a wild-type (E) and PR mutant (F) duct confirms the complete absence of terminal-end buds in the PR mutant. Scale bar, $20 \mu \mathrm{m}$. (With permission from [30])

velopment of the mammary gland is independent of either hormone; however, development and growth during puberty is heavily dependent on the actions of estradiol via the $\mathrm{ER} \alpha$. Mammary tissue from adult virgin wild-type female mice is reportedly negative for ER $\beta$ mRNA [26]. Secondly, differentiation of the gland as well as further growth during pregnancy appears to be heavily coordinated by progesterone and the PR. In conclusion, both of these transgenic models may prove invaluable in the study of the role of steroid hormones in mammary neoplasia. The role of estrogen and progesterone and their respective receptors in the initiation and maintenance of human breast tumors has been the subject of intense study [63]. The studies described above have confirmed, at least in the mouse, that both steroids are potent mitogens at specific stages of growth in normal mammary tissue. 


\section{Behavior}

In the mammalian brain, as in the reproductive tract, the sex steroid hormones are known to play both an "organizational" role during critical periods of development and an "activational" role during adulthood (reviewed in $[5,64$, 65]). This is evident in studies in the rat in which (a) castration on the day of birth results in a feminized adult male that exhibits a female pattern of behavioral responses when treated with estradiol and progesterone, and (b) neonatal testosterone treatment of a female results in a masculinized adult that is refractory to estradiol and progesterone $[4,65]$. The culmination of the data collected from such experimental schemes is that testosterone secreted from the perinatal testes during a critical developmental window results in permanent changes in the hypothalamic nuclei of the brain that mediate male sexual behavior [4, 65]. However, estradiol is also necessary for normal development of the female brain, although in lower amounts [4]. In fact many of the masculinizing effects of perinatal testosterone appear to be via local aromatization of the hormone to estradiol and subsequent activation of the ER signaling pathway [66].

Studies have indicated that the imprinting mechanisms controlled by the sex steroids in the brain may be via regulation of cell death, neuronal growth, and synaptogenesis $[5,64]$. These effects are considered permanent and are generally thought to be genomic events mediated via the nuclear receptor pathways [5, 67]. Indeed, the nuclear receptors for estrogen, androgen, and progesterone have all been detected in the fetal, neonatal, and adult brain [13, 65]. However, sex steroids and their metabolites have also been documented to produce rapid neural responses in the brain, such as stimulation of the GABAa-benzodiazepine receptor, and the mobilization of calcium ions across cell membranes (reviewed in [5, 68]). It is believed that these effects occur too rapidly to be mediated by the classical mechanism of nuclear receptor actions, and they have therefore been termed "nongenomic" and are possibly mediated by membrane receptors $[5,68]$. The exact role of nongenomic actions of steroids in the proper organization and function of the mammalian brain are unknown. Therefore the Tfm, ERKO, and PR mutant mice provide excellent models not only for studying the role of the nuclear receptors but also for investigating steroid actions that may not be mediated by nuclear receptor mechanisms.

Studies utilizing the nuclear steroid receptor deficient mice have focused primarily on behavioral phenotypes and their response to steroid activators during adulthood. However, in considering these data it is important to recognize that the brains of the adult mutant mice were "organized" in the absence of the respective sex steroid receptors and therefore cannot be assumed to be similar to the wild-type adult. Therefore it is difficult to distinguish between an organizational and an activational basis for an observed deficit in behavior in the mutant mice. However, this limitation in considering data from a single model of sex steroid receptor deficiency may be overcome to some extent when data from the three models are considered together. Yet another limit on the breadth of the indications of these studies are the several differences that have been reported on the species, strain, and particular sexual dimorphism being studied [4].

Prior to the availability of the ERKO mouse, McCarthy et al. [69] employed an elaborate technique of infusing oligodeoxynucleotides into the neonatal rat hypothalamus to elucidate a direct role for ER $\alpha$ in the sexual differentiation of the female brain. The presence of specific ER $\alpha$ antisense oligodeoxynucleotides in the hypothalamus would interfere with proper expression of the ER $\alpha$ gene during this critical window of brain organization [69]. The experimental groups included neonatal rats treated with testosterone plus or minus the infusion of the $\mathrm{ER} \alpha$ antisense oligodeoxynucleotides. As adults those females infused with the $\operatorname{ER} \alpha$ antisense oligodeoxynucleotides exhibited more female sexual behavior than those treated with androgen alone, indicating that reduced ER $\alpha$ expression protects infused rats from the masculinizing effects of testosterone exposure [69]. This study provided strong evidence that estradiol activation of the ER $\alpha$ pathway does indeed play a primary role in the masculinization of the rat brain.

Although it may appear that females derived from the experimental scheme of McCarthy et al. resemble the ERKO female, it is important to recognize that the ERKO are deficient in $\mathrm{ER} \alpha$ throughout life and therefore are likely resistant to the activating effects of estradiol during adulthood as well. A recent report by Ogawa et al. [70] demonstrated that intact adult ERKO females tend to behave more as males in terms of parental, aggressive, and sexual behavior. When placed with sexually experienced wild-type males, intact ERKO females showed a significant decrease in the lordosis response, a behavior indicative of sexual receptivity, than wild-type females [70]. In fact the intact ERKO females were often treated as an intruder by the stud male, a behavior most likely elicited by the significantly elevated levels of circulating testosterone in the ERKO female [70]. Resistance to steroid activators was reported in a similar study by Rissman et al. [71] in which ovariectomized ERKO females exhibited decreased sexual receptivity even after treatments with estradiol, or estradiol plus progesterone. However, the elicitation of increased aggression from the stud male was eradicated with ovariectomy in the ERKO female in this study [71]. The findings from these studies confirm a role for the estradi$\mathrm{ol} / \mathrm{ER} \alpha$ pathway in female sexual behavior. The ERKO females have also exhibited a significantly decreased capacity for maternal behavior [71], a finding that is consistent with previous studies showing a possible role for ER $\alpha$ in parenting [72].

As in the tissues of the reproductive tract, the PR in female neural tissues is under the regulation of the estrogen/ER pathway. Therefore the reproductive behavioral phenotypes observed in the ERKO female may be compounded by or even a direct result of the attenuation of PR levels in the brain. Prior to the generation of the PR mutant mice, a role for PR in female reproductive behavior was also indicated by studies utilizing the technology of 
antisense oligonucleotide infusion of the hypothalamus to inhibit the transcription of the PR gene [73-75]. Since this time, studies by Lydon et al. [30] of the PR mutant female have shown that neural PR is apparently required for the lordosis response in the mouse. When both wild-type and PR mutant females were estrogen primed and placed with stud wild-type male mice, no significant lordosis responses were observed in either genotype [30]. However, upon the additional administration of progesterone, wild-type mice exhibited a substantial increase in lordosis response, whereas that in the PR mutant remain unchanged [30]. Therefore, it is the estrogen-induced PR in the hypothalamus that is critical to a proper sexual response in the female mouse [30]. In addition, O'Malley and colleagues [76] have demonstrated ligand-independent activation of the PR by the neurotransmitter dopamine and have postulated that dopamine-induced sexual behaviors require the presence of hypothalamic PR [77]. Their recent report using the PR mutant female confirms that the sexual behavior induced by dopamine does indeed require the presence of unoccupied PR in the medial basal hypothalamus [78].

\section{Reproductive phenotypes in male mice}

The testes

The development of the undifferentiated fetal gonad to either a testis or ovary is determined by the presence or absence of a testis determining factor or gene localized to the Y chromosome [3]. Once the fetal testes are present, their subsequent secretion of testosterone and antimüllerian hormone are essential to the proper differentiation of the internal structures of the male reproductive tract. During later sexual maturation, the more potent testosterone metabolite, DHT, results in virulization of the external genitalia [14]. This is in contrast to the female in which fetal differentiation and development of the reproductive tract are independent of the steroid hormones, as described above. This fact is evident from the feminized phenotype that results from the lack of AR in the syndrome of human cAIS and in the Tfm mouse. Several of the phenotypes in the Tfm mouse are congruent with human cAIS, characterized by the complete absence of either male or female internal reproductive structures besides the presence of inguinal testes. External genitalia are indistinguishable from the normal female; however, the vagina is short and often blunt-ended $[14,16]$.

There are a large number of reports describing the human AIS, thereby allowing researchers relatively easy access to subjects for study. For this reason little is known about the full effects of androgen insensitivity in the Tfm mouse. The breadth of the continuing documentation of human AIS is beyond the scope of this review; however, the authors encourage the interested reader to seek several of the referenced reviews $[14,15,79,80]$.

The testes of Tfm mice are smaller and are consistently found in the inguinal region upon dissection. The precise
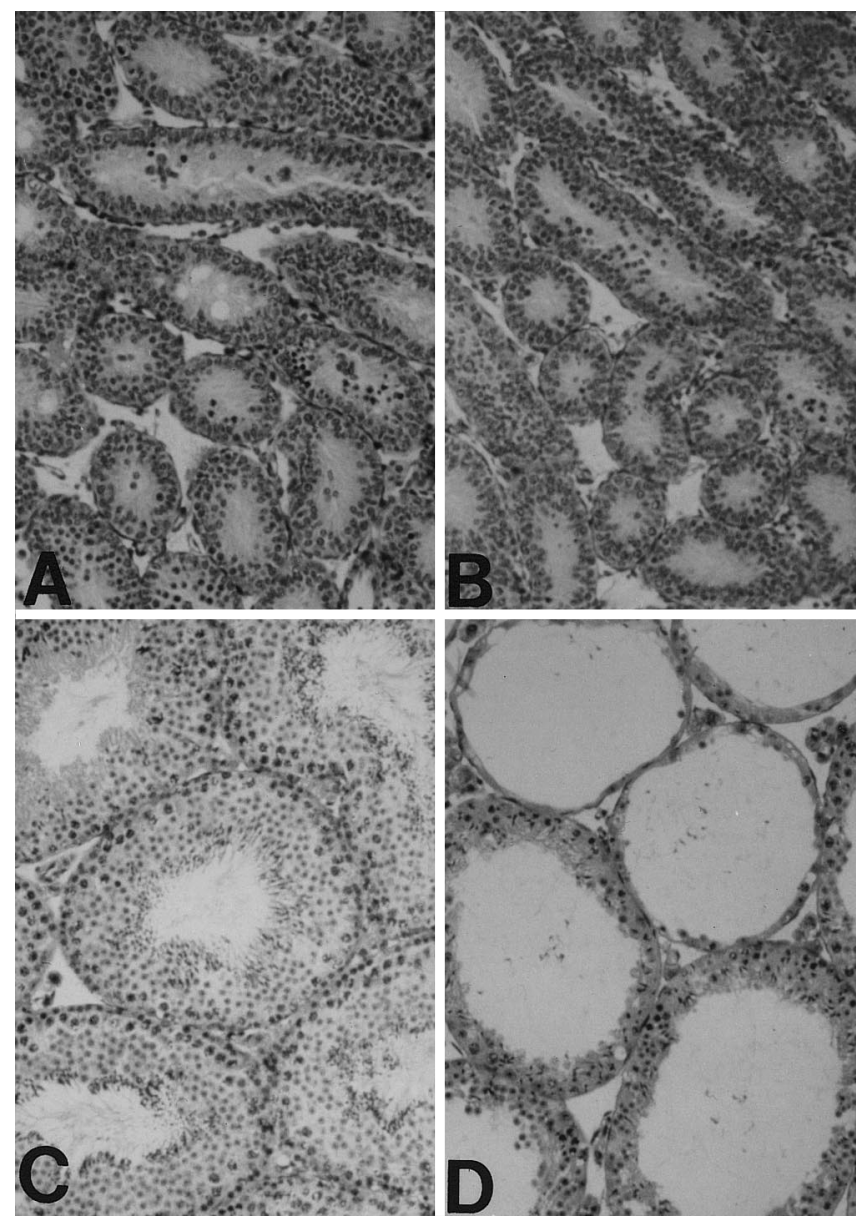

Fig. 5A-D Histology of testes from juvenile and adult wild-type and ERKO mice. A The testis of a 10-day-old wild-type mouse. The seminiferous cords are packed loosely, and interstitial spaces are present at scattered positions. The seminiferous epithelium consists of Sertoli cells and speratogonia with nuclei lying near the periphery of the tubule. B The testis of a 10-day-old ERKO mouse. The appearance of the seminiferous cords are comparable to those in the wild-type. C The testis of an 80-day-old wild-type mouse. The seminiferous tubules are closely packed and at different stages of spermatogenesis. The interstitium is filled with Leydig cells and connective tissue. D The testis of an 80-day-old ERKO mouse. The interstitium appears somewhat expanded compared to the wild-type. The seminiferous epithelium is low, and the tubule lumen is dilated. (From [87])

role of androgens in testicular descent has long been controversial. However, in a series of experiments Hutson and colleagues [81, 82] have used the Tfm mouse to reveal strong evidence in support of a biphasic model of testicular descent in which androgens are critical to the second step of testis migration, i.e., from the internal inguinal ring to the scrotum via action on the genitoinguinal ligament (or gubernaculum).

As in the female, gonadal steroidogenesis and germ cell maturation in the male is dependent on the pituitary gonadotropins LH and FSH. Androgens are able to regulate LH and FSH production and/or secretion in a negative feedback fashion via actions on the hypothalamus and pituitary [14]. Therefore, due to the lack of functional AR and the 
subsequent ablation of this feedback loop, both LH and FSH levels are elevated in the Tfm mouse [83]. Spermatogonia and Sertoli cells are present in the testes of Tfm mice; however, spermatogenesis seldom proceeds beyond the spermatocyte stage [16]. Leydig cells, the testicular cell principally responsible for androgen production via stimulation by $\mathrm{LH}$, appear equal in number to wild-type mice but are hypertrophied in the testes of Tfm mice [16, 84]. However, even in the presence of abnormally high levels of circulating $\mathrm{LH}$, testosterone production and circulation in the Tfm are significantly lower than in wildtype mice [85]. This is due primarily to decreased activity of the required steroidogenic enzyme $17 \alpha$-hydroxylase in the Leydig cells $[85,86]$ and is compounded by the intraabdominal position of the testis, a factor also known to decrease enzyme activity [85]. Normally, androgen action via the AR in Leydig cells plays a negative regulatory role on this enzyme in the adult. This paradox has prompted the authors to propose that the lack of AR during development results in permanent changes in enzyme activity in the Tfm testes [85]. Finally, it is worthy to note that both the presence of spermatogenesis in the testes and the low level of circulating androgens in the Tfm mouse are in contrast to observations reported in the human AIS [14, 15].

Infertility in the male $\mathrm{Tfm}$ as well as in the female ERKO was a rather expected phenotype given the extensive roles of the respective hormone signaling systems in each sex. However, a phenotype of complete infertility in the ERKO male as described by Eddy et al. [87] was quite surprising. As expected in the presence of a functional androgen signaling system, the reproductive tract of the ERKO male grossly appears to have developed prenatally to produce the proper morphological structures. However, a report by Donaldson et al. [88] indicated a smaller yet more muscular cremaster sac and a greater incidence of retraction of the testes into the abdomen in ERKO males than in wildtype counterparts, suggesting a previously unrecognized role for the ER $\alpha$ in development of the male reproductive tract. Furthermore, sexually mature ERKO males had significantly lower testicular weight than wild-type males, although changes in the epididymis, seminal vesicles, coagulating glands, and prostate were not evident $[87,88]$.

Histological analysis of adult ERKO testes reveals the presence of severely atrophied and degenerated seminiferous tubules, often possessing a dilated lumen and only a thin lining of Sertoli cells, as well as a disorganized semi- niferous epithelium with few spermatogenic cells (Fig. 5) [87]. It has been suggested that this phenotype is due to a disruption of the fluid transport mechanisms in the testis, possibly as a result of the lack of normal cell-cell contacts and coupled with alterations in the cellular ion channels in the seminiferous epithelium, as well as possibly an overall decreased rate of fluid reabsorption in the efferent ductules [87]. This phenotype appears to be age-related, commencing at approximately 10-12 weeks of age and progressing in a wave from the caudal pole toward the cranial pole of the testis [87]. A possible explanation for this phenomenon is that the accumulation of fluid in the testis leads to increased testicular pressure and therefore possibly decreased blood flow, first becoming apparent in the less vascularized caudal pole of the organ [87].

Testicular steroidogenesis in the ERKO does not appear to be greatly altered, nor does the circulating levels of $\mathrm{LH}$ and FSH [87]. These results provide strong evidence that steroidal feedback on the hypothalamic-pituitary axis in male mice is androgen/AR-mediated and not dependent on aromatization of testosterone to estradiol and subsequent ER actions. Nonetheless, infertility in the ERKO male is the result of distinct phenotypes in multiple aspects of male reproduction. Spermatogenesis in the ERKO male appears to be present until approximately 10-12 weeks of age, when epididymal sperm concentrations decrease substantially (Table 1), coinciding with the onset of the abnormal dilation of the seminiferous tubules described above [87]. However, the reproductive capacity of sperm from ERKO males is significantly compromised even prior to the overall decrease in counts. Epididymal samples collected from ERKO males have been found to possess sperm with less vigorous motility and an overall lower percentage of motile sperm than in age-matched wildtypes (Table 1) [87]. Furthermore, in vitro fertilization experiments using equal numbers of motile sperm from wildtype and ERKO males demonstrated a complete failure of ERKO sperm to fertilize (Table 1) [87]. Previous studies have suggested a role for the estrogen/ER pathway on Sertoli, spermatogenic, and epididymal epithelial cell functions [89] as well as in sperm transport and maturation within the epididymis [90]. These studies, combined with that of the ERKO, have provided evidence to support a requirement for $\mathrm{ER} \alpha$ in spematogenesis and fertility in the male mouse; however, the exact mechanisms disrupted by the lack of $E R \alpha$ require further investigation.

\begin{tabular}{|c|c|c|c|c|c|c|c|c|c|c|c|c|}
\hline \multirow[b]{3}{*}{$\begin{array}{l}\text { Age } \\
\text { (weeks) }\end{array}$} & \multicolumn{4}{|c|}{$\begin{array}{l}\text { Sperm counts } \\
\left(10^{6} / \mathrm{ml}\right)\end{array}$} & \multicolumn{4}{|c|}{$\begin{array}{l}\text { Sperm motility } \\
(\%)\end{array}$} & \multicolumn{4}{|c|}{$\begin{array}{l}\text { In vitro fertilization } \\
(\%)\end{array}$} \\
\hline & \multicolumn{2}{|c|}{ Wild-type } & \multicolumn{2}{|c|}{ ERKO } & \multicolumn{2}{|c|}{ Wild-type } & \multicolumn{2}{|c|}{ ERKO } & \multicolumn{2}{|c|}{ Wild-type } & \multicolumn{2}{|c|}{ ERKO } \\
\hline & $\mathrm{n}$ & Mean & $n$ & Mean & $n$ & Mean & $n$ & Mean & $n$ & Mean & $n$ & Mean \\
\hline 8 & 3 & $37 \pm 19$ & 3 & $21 \pm 12$ & 4 & $58 \pm 88$ & 3 & $17 \pm 3 * *$ & 3 & $6 \pm 6$ & 2 & $0 \pm 0$ \\
\hline 10 & 4 & $26 \pm 2$ & 4 & $21 \pm 4$ & 4 & $58 \pm 5$ & 4 & $23 \pm 1 * *$ & 4 & $13 \pm 8$ & 4 & $1 \pm 1$ \\
\hline $12-13$ & 3 & $35 \pm 4$ & 4 & $6 \pm 2 *$ & 3 & $57 \pm 7$ & 3 & $7 \pm 3 *$ & 3 & $14 \pm 9$ & 3 & $0 \pm 0$ \\
\hline $15-16$ & 4 & $43 \pm 7$ & 4 & $6 \pm 4^{*}$ & 4 & $55 \pm 5$ & 4 & $0.5 \pm 0.3 *$ & 3 & $4 \pm 4$ & 4 & $0 \pm 0$ \\
\hline
\end{tabular}

Table 1 Sperm function in wildtype and ERKO male mice as it relates to age (from [87])

$$
\begin{aligned}
& * P<0.004 \text { wild-type vs. ERKO } \\
& (t \text { test }) \\
& * * P<0.03 \text { wild-type vs. ERKO }
\end{aligned}
$$$$
\text { ( } t \text { test) }
$$ 
Behavior

Behavioral studies on the Tfm mouse are complicated by the fact that the animal lacks the respective sex steroid receptor throughout life. However, as discussed above, masculinization of the mammalian brain is thought to depend heavily on the estrogen/ER pathway, which should be intact in the Tfm mouse. The difficulties arise in that the $\mathrm{Tfm}$ is refractory to androgen, the masculine activating hormone, during adulthood. This same paradigm, although reversed in terms of the AR and ER $\alpha$ signaling systems, exists in the ERKO male. Despite these limitations the experimental data viewed in combination will surely shed light on the roles of the AR and ER $\alpha$ in masculinization and defeminization of the male brain.

The Tfm mouse was originally described as exhibiting sexual and aggressive behavior similar to that of a nonestrous female [16], indicating a significant role for the AR in male behavior. Ohno et al. [91] further reported that Tfm mice exhibit neither male nor female behavior and are refractory to both estradiol and testosterone as activators in adulthood. More extensive studies by Olsen have shown that both intact Tfm mice and those that are castrated and treated with either testosterone, estrogen, DHT, or estrogen plus DHT exhibit little male-typical mating behavior in terms of mounting, intromission, and ejaculation (reviewed in [4]). Furthermore, treatments with estrogen or estrogen plus progesterone result in levels of female mating behavior that are typical of a similarly treated wildtype male [4]. It is important to note that distinct differences in sexual behaviors exist between the Tfm mouse and the Tfm rat (reviewed in [4]). Studies have shown the $\mathrm{Tfm}$ rat to be somewhat sensitive to the actions of androgen in activating male sexual behavior whereas the Tfm mouse is completely resistant [4, 92].

In the ERKO male, Ogawa et al. [93] have surprisingly shown that a lack of hypothalamic ER $\alpha$ during development has little effect on mounting behavior and sexual motivation toward wild-type females. However, the same studies conclude that ERKO males exhibit an almost complete lack of intromission and ejaculation, even though the number and frequency of mounts are equivalent to those of wild-type males [93]. This phenotype could not be rescued by exogenous treatment with the nonaromatizable androgen DHT, providing evidence that these actions depend on $\mathrm{ER} \alpha$ for organization of the proper circuitry and/or during activation [93]. This behavioral phenotype is a contributing factor to the infertility of the ERKO male [93]. Furthermore, ERKO males are consistently less aggressive than their wild-type counterparts, exhibiting aggressive behaviors more typical of female mice [93].

The findings from the various studies employing the Tfm and ERKO male mice confirm that proper development and activation of masculine behavior depend on both the AR and ER $\alpha$ pathways. However, it appears that only discrete components of sexual and social behavior in the male mouse are dependent on the actions of $\mathrm{ER} \alpha$ since the ERKO male exhibits relatively normal levels of mounting but profound deficits in intromission. It is possible that the organization of mounting behaviors is mediated by the AR. However, recent studies have now indicated the presence of ER $\beta$ in the hypothalamus of the mouse [26] and rat [94], thereby suggesting the possibility that distinct imprinting actions of estradiol are mediated by this newly discovered receptor. We have since shown that ERKO males possess relatively normal levels of ER $\beta$ mRNA in the brain and therefore should prove an invaluable tool in determining whether ER $\alpha$ or ER $\beta$ regulates the organization and activation of discrete components of male sexual behavior [26].

\section{Nonreproductive phenotypes}

\section{The skeletal system}

Albright et al. [95] in 1941 were the first to describe a link between osteoporosis and the decreasing estrogen levels in postmenopausal women. Since then estrogen replacement therapy in postmenopausal women as well as in animal models has been shown to be an effective treatment in preventing this disease, although the effects of steroid hormones on bone metabolism were long thought to be indirect. However, more recent studies have demonstrated the presence of $\mathrm{AR}$ and $\mathrm{ER} \alpha$ as well as the direct effects of their respective steroid ligands in osteoblasts and osteoclasts of mammals [96-100].

The majority of bone morphology and metabolism studies in an animal model have been carried out in the rat (reviewed in [101]). However, a series of reports by $\mathrm{Mi}$ gliaccio et al. [102, 103] have demonstrated that increased exposure to the synthetic estrogen/DES, during prenatal and neonatal development results in shorter femur length, significantly increased cortical bone thickness, and increased trabecular bone at the epiphysis of the femur in adult female mice. Interestingly, a study of the Tfm rat indicated that it is indeed androgen/AR actions that are critical to longitudinal and radial bone growth; however, endogenous estrogens are able to maintain the cancellous bone mass in these animals [104]. Therefore forthcoming studies of bone development and physiology in the ERKO mice should prove very intriguing. However, it is noteworthy that the first description of a human case of estrogen insensitivity involved an extensive bone phenotype in which the patient suffered from both severe osteoporosis and insufficient closure of the epiphyseal growth plates [22].

\section{Circulatory system}

A remarkable difference in the risk of coronary heart disease between the sexes has been known to exist since the early part of this century (reviewed in [105]). Although women generally possess a greater incidence of the multiple risk factors associated with coronary heart disease, such as obesity, high blood pressure, high plasma cholesterol levels, and diabetes, their risk of contracting this dis- 
ease is significantly lower than that of men [106]. A number of studies of the human population as well as experimental research in animals have shown that the protective factor in females is the steroid hormone estradiol (reviewed in [106]). Therefore studies utilizing the ERKO line of transgenic mice are currently underway in an attempt to determine the possible mechanisms by which estrogens reduce the risk of cardiovascular disease. These efforts to date have demonstrated such abnormal phenotypes in the ERKO mice as compromised nitric oxide synthesis in the aorta [107] and a lack of estrogen-induced angiogenesis [108]. However, Mendelsohn et al. [109] utilizing the vascular injury model, have recently demonstrated that ERKO female mice exhibit the same protective effects of 17-Bestradiol as their wild-type littermates, indicating that $\mathrm{ER} \alpha$ may not be required for the protective actions of estradiol on the vascular system. It is possible that this is the first ER $\beta$-mediated estrogen effect to be described. However, rapid effects of estradiol on the vascular tissue, such as changes in vasomoter tone, available nitric oxide, and resting potential of smooth muscle cells, have been previously described and postulated to be mediated by an elusive membrane receptor for estrogen [110]. The ERKO mouse should prove to be effective in these ongoing investigations of estrogens effects in the cardiovascular system.

\section{Summary}

In this review we attempt to provide an insightful summary of the data collected to date from the existing mouse models of sex steroid receptor deficiency. Although the generation and initial characterizations of the ERKO and PR mutant transgenic lines have proved exciting, it is worthy to note that these models are relatively new to the field. These mice will undoubtedly prove invaluable to future studies of steroid hormones in normal development and function, for example, further studies of the documented "nongenomic" effects of estradiol and progesterone in the brain (reviewed in $[5,68]$ ) and progesterone on spermatozoa (reviewed in [111]), ligand-independent actions involving cross-talk with other signaling systems, and the role of ER $\beta$ in the estrogen signaling system, to name a few. Therefore there is reason to believe that the forthcoming descriptions of unique phenotypes and the employment of these mutant mice in dissecting the many interactions and functions of the sex steroid hormones in the mammal will be exciting.

\section{References}

1. Jost A (1970) Hormonal factors in the sex differentiation of the mammalian foetus. Philos Trans R Soc Lond 259:119-130

2. Jost A (1985) Sexual organogenesis. In: Adler N, Pfaff D, Goy RW (eds) Handbook of behavioral neurobiology. Plenum, New York, pp 3-19

3. Hughes IA, Pinsky L (1989) Sexual differentiation. In: Collu R, Ducharme JR, Guyda HJ (eds) Pediatric endocrinology. Raven, New York, pp 250-293

4. Olsen KL (1992) Genetic influences on sexual behavior differentiation. In: Gerall AA, Moltz H, Ward IL (eds) Handbook of be- havioral neurobiology: sexual differentiation, vol 11. Plenum, New York, pp 1-40

5. McEwen BS (1992) Effects of the steroid/thyroid hormone family on neural and behavioral plasticity. In: Nemeroff CB (ed) Neuroendocrinology. CRC, Boca Raton, pp 333-351

6. McLachlan JA, Newbold RR, Bullock BC (1975) Reproductive tract lesions in male mice exposed prenatally to diethylstilbestrol. Science 190:991-992

7. Newbold RR, McLachlan JA (1982) Vaginal adenosis and adenocarcinoma in mice prenatally or neonatally exposed to diethylstilbestrol. Cancer Res 42:2003-2011

8. McLachlan JA, Newbold RR, Bullock BC (1980) Long-term effects on the female mouse genital tract associated with prenatal exposure to diethylstilbestrol. Cancer Res 40:3988-3999

9. Forsberg J-G, Kalland T (1981) Neonatal estrogen treatment and epithelial abnormalities in the cervicovaginal epithelium of adult mice. Cancer Res 41:721-734

10. Arai Y, Matsumoto A, Yamanouchi K, Nichizuka M (1980) Perinatal sex steroid exposure, brain morphology, and neuroendocrine and behavioral functions. In: Mori T, Nagasawa H (eds) Toxicity of hormones in perinatal life. CRC, Boca Raton, pp 9-20

11. Mahendroo MS, Cala KM, Landrum CP, Russell DW (1997) Fetal death in mice lacking $5 \alpha$-reductase type 1 caused by estrogen excess. Mol Endocrinol 11:917-927

12. Mangelsdorf DJ, Thummel C, Beato M, Herrlich P, Schutz G, Umesono K, Blumberg B, Kastner P, Mark M, Chambon P, Evans RM (1995) The nuclear receptor superfamily: the second decade. Cell 83:935-839

13. Cunha GR, Cooke PS, Bigsby R, Brody JR (1991) Ontogeny of sex steroid receptors in mammals. In: Parker MG (ed) Nuclear hormone receptors: molecular mechanisms, cellular functions, clinical abnormalities. Academic, London, pp 235-268

14. Patterson MN, McPhaul MJ, Hughes IA (1994) Androgen insensitivity syndrome. In: Sheppard MC, Stewart PM (eds) Bailliere's clinical endocrinology and methabolism: hormones, enzymes and receptors. Bailliere Tindall, London, pp 379-404

15. Lindzey J, Kumar MV, Grossman M, Young C, Tindall DJ (1994) Molecular mechanisms of androgen action. In: Litwak G (ed) Steroids. Academic, San Diego, pp 383-432

16. Lyon MF, Hawkes SG (1970) X-linked gene for testicular feminization. Nature 227:1217-1219

17. Gaspar M-L, Meo T, Bourgarel P, Guenet J-L, Tosi M (1991) A single base deletion in the Tfm androgen receptor gene creates a short-lived messenger RNA that directs internal translation initiation. Proc Natl Acad Sci USA 88:8606-8610

18. Young CYF. Johnson MP, Prescott JL, Tindall DJ (1989) The androgen receptor of the testicular-feminized (Tfm) mutant mouse is smaller than the wild-type receptor. Endocrinology 124: 771-775

19. Lyon MF, Glenister PH (1980) Reduced reproductive performance in androgen-resistant $\mathrm{Tfm} / \mathrm{Tfm}$ female mice. Proc $\mathrm{R}$ Soc Lond B Biol Sci 208:1-12

20. Chatterjee VKK. Beck-Peccoz P (1994) Thyroid hormone resistance. In: Sheppard MC, Stewart PM (eds) Bailliere's clinical endocrinology and metabolism: hormones, enzymes and receptors. Bailliere Tindall, London, pp 267-283

21. Lubahn DB, Moyer JS, Golding TS, Couse JF, Korach KS, Smithies O (1993) Alteration of reproductive function but not prenatal sexual development after insertional disruption of the mouse estrogen receptor gene. Proc Natl Acad Sci USA 90:11162-11166

22. Smith EP, Boyd J, Frank G, Takahashi H, Cohen RM, Specker B, Williams TC, Lubahn DB, Korach KS (1994) Estrogen resistance caused by a mutation in the estrogen-receptor gene in a man. $\mathrm{N}$ Engl J Med 331:1056-1061

23. Kuiper GGJM. Enmark E, Pelto-Huikko M, Nilsson S, Gustafsson J-Å (1996) Cloning of a novel estrogen receptor expressed in rat prostate and ovary. Proc Natl Acad Sci USA 93:5925-5930

24. Tremblay GB, Tremblay A, Copeland NG, Gilbert DJ, Jenkins NA, Labrie F, Giguere V (1997) Cloning, chromosomal localization, and functional analysis of the murine estrogen receptor $\beta$. Mol Endocrinol 11:353-365

25. Mosselman S, Polman J, Dijkema R (1996) ER $\beta$ : identification and characterization of a novel human estrogen receptor. FEBS Lett 392:49-53 
26. Couse JF, Lindzey J, Grandien K, Gustafsson J-Å, Korach KS (1997) Tissue distribution and quantitative analysis of estrogen receptor- $\alpha(E R \alpha)$ and estrogen receptor- $\beta(E R \beta)$ mRNA in the wild-type and ER $\alpha$-knockout mouse. Endocrinology 11:4613-4621

27. Clarke CL, Sutherland RL (1990) Progestin regulation of cellular proliferation. Endocrine Rev 11:266-300

28. Wei LL (1996) New models and insights in steroid hormone action. In: Pavlik EJ (ed) Estrogens, progestins, and their antagonists, vol 2. Birkhauser, Boston, pp 101-121

29. Kastner P, Krust A, Turcotte B, Stropp U, Tora L, Gronemeyer H, Chambon P (1990) Two distinct estrogen-regulated promoters generate transcripts encoding the two functionally different human progesterone receptor forms A and B. EMBO J 9:1603-1614

30. Lydon JP, DeMayo FJ, Funk CR, Mani D, Hughes AR, Montgomery CA Jr, Shyamala G, Conneely OM, O'Malley BW (1995) Mice lacking progesterone receptor exhibit pleiotropic reproductive abnormalities. Genes Dev 9:2266-2278

31. Lydon JP, DeMayo FJ, Conneely OM, O’Malley BW (1996) Reproductive phenotypes of the progesterone receptor null mutant mouse. J Steroid Biochem Mol Biol 56:67-77

32. Huet-Hudson YM, Dey SK (1990) Differential effects of ovarian steroids and triphenylethylene compounds on macromolecular uptake and thymidine incorporation in the mouse uterus. J Steroid Biochem 35:23-27

33. Clark JH, Schrader WT, O'Malley WC Jr (1985) Mechanisms of steroid hormone action. In: Wilson JD, Foster DW (eds) Textbook of endocrinology. Saunders, Philadelphia, pp 33-75

34. Korach KS (1994) Insights from the study of animals lacking functional estrogen receptor. Science 266:1524-1527

35. Korach KS, Couse JF, Curtis SW, Washburn TF, Lindzey J, Kimbro KS, Eddy EM, Micliaccio S, Snedeker SM, Lubahn DB, Schomberg DW, Smith EP (1996) Estrogen receptor gene disruption: molecular characterization and experimental and clinical phenotypes. Rec Prog Horm Res 51:159-188

36. Couse JF, Curtis SW, Washburn TF, Lindzey J, Golding TS, Lubahn DB, Smithies O, Korach KS (1995) Analysis of transcription and estrogen insensitivity in the female mouse after targeted disruption of the estrogen receptor gene. Mol Endocrinol 9:1441-1454

37. Liu Y, Teng C (1992) Estrogen response module of the mouse lactoferrin gene contains overlapping chicken ovalbumin upstream promoter transcription factor and estrogen receptor-binding elements. Mol Endocrinol 6:355-364

38. DiAugustine RP, Petruez P, Bell GI, Brown CF, Korach KS, McLachlan JA, Teng CT (1988) Influence of estrogens on mouse uterine epidermal growth factor percursor protein and messenger ribonucleic acid. Endocrinology 122:2355-2363

39. Nelson KG, Takahashi T, Bossert NL, Walmer DK, McLachlan JA (1991) Epidermal growth factor replaces estrogen in the stimulation of female genital-tract growth and differentiation. Proc Natl Acad Sci USA 88:21-25

40. Ignar-Trowbridge DM, Nelson KG, Bidwell MC, Curtis SW, Washburn TF, McLachlan JA, Korach KS (1992) Coupling of dual signalling pathways: epidermal growth factor action involves the estrogen receptor. Proc Natl Acad Sci USA 89:4658-4662

41. Curtis SW, Washburn T, Sewall C, DiAugustine R, Lindzey J, Couse JF, Korach KS (1996) Physiological coupling of growth factor and steroid receptor signaling pathways: estrogen receptor knockout mice lack estrogen-like response to EGF. Proc Natl Acad Sci USA 93:12626-12630

42. Quarmby VE, Korach KS (1984) The influence of 17ß-estradiol on patterns of cell division in the uterus. Endocrinology 114:694-702

43. Kelly RW, Leask R, Calder AA (1992) Choriodecidual production of interleukin-8 and mechanism of parturition. Lancet 339:776-777

44. Ito A, Imada K, Takashi S, Kubo T, Matsushima K, Mori Y (1994) Suppression of interleukin 8 production by progesterone in rabbit uterine cervix. Biochem J 301:183-186

45. Cheung L, Kelly RW, Thong KJ, Hume R, Baird DT (1993) The effect of mifepristone (RU486) on the immunohistochemical distribution of prostagland $\mathrm{E}$ and its metabolite in decidual and chorronic tissue in early pregnancy. J Clin Endocrinol Metab 77:873-877
46. Hewison M, O'Riordan JLH (1994) Vitamin D resistance. In: Sheppard MC, Stewart PM (eds) Bailliere's clinical endocrinology and metabolism: hormones, enzymes and receptors. Bailliere Tindall, London, pp 305-315

47. Hillier SG (1994) Current concepts of the roles of follicle stimulating hormone and luteinizing hormone in folliculogenesis. Human Reprod 9:188-191

48. Shupnik MA (1996) Gonadal hormone feedback on pituitary gonadotropin genes. Trends Endocrinol Metab 7:272-276

49. Scully KM, Gleiberman AS, Lindzey J, Lubahn DB, Korach KS, Rosenfeld MG (1997) Role of estrogen receptor $\alpha$ in the anterior pituitary gland. Mol Endocrinol 11:674-681

50. Risma KA, Clay CM, Nett TM, Wagner T, Yun J, Nilson JH (1995) Targeted overexpression of leutinizing hormone in transgenic mice leads to infertility, polycystic ovaries, and ovarian tumors. Proc Natl Acad Sci USA 92:1322-1326

51. Risma KA, Hirshfield AN, Nilson JH (1997) Elevated luteinizing hormone in prepubertal transgenic mice causes hyperandrogenemia, precocious puberty, and substantial ovarian pathology. Endocrinology 138:3540-3547

52. Richards JS (1975) Estradiol receptor content in rat granulosa cells during follicular development: modification by estradiol and gonadotropins. Endocrinology 97:1174-1184

53. Dukes M, Chester R, Yarwood L, Wakeling AE (1994) Effects of a non-steroidal pure antiestrogen, ZM 189,154, on oestrogen target organs of the rat including bones. J Endocrinol 141:335-341

54. Hsueh AJW. Billig H, Tsafriri A (1994) Ovarian follicle atresia: a hormonally controlled apoptotic process. Endocrine Rev 15:707-724

55. Lindzey J, Curtis S, Washburn T, Korach K (1996) Uterotropic effects of dihydrotestosterone in estrogen receptor knockout and wild type mice. 10th International Congress of Endocrinology, (abstract) OR18-4:77

56. Tanaka N, Espey LL, Stacy S, Okamura H (1992) Epostane and indomethacin actions on ovarian kallikrein and plaominogen activator activities during ovulation in the gonadotropin-primed immature rat. Biol Reprod 46:665-670

57. Loutradis D, Bletsa R, Aravantinos L, Kallianidis K, Michalas S, Psychoyos A (1991) Preovulatory effects of the progesterone antagonsist mifepristone (RU486) in mice. Human Reprod 6:1238-1240

58. Richards JS (1994) Hormonal control of gene expression in the ovary. Endocrine Rev 15:725-751

59. Chandrasekher YA, Melner MH, Nagalla SR, Stouffer RL (1994) Progesterone receptor, but not estradiol receptor, messenger ribonucleic acid is expressed in luteinizing granulosa cells and the corpus luteum in rhesus monkeys. Endocrinology 135:307-314

60. Imagawa W, Yang J, Guzman R, Nandi S (1994) Control of mammary gland development. In: Knobil E, Neill JD (eds) The physiology of reproduction, 2nd edn. Raven, New York, pp 1033-1063

61. Dickson RB, Lippman ME (1995) Growth factors in breast cancer. Endocrine Rev 16:559-589

62. Amara JF, Van Itallie C, Dannies PS (1987) Regulation of prolactin production and cell growth by estradiol: difference in sensitivity to estradiol occurs at level of messenger ribonucleic acid accumulation. Endocrinology 120:264-271

63. Mansour EG, Ravdin PM (1994) Prognostic factors in early breast cancer. Cancer 74:381-400

64. Pilgrim C, Hutchison JB (1994) Developmental regulation of sex differences in the brain: can the role of gonadal steroids be redefined? Neuroscience 60:843-855.

65. McEwen BS (1992) Steroid hormones: effect on brain development and function. Horm Res 37[Suppl 3]:1-10

66. Negri-Cesi P, Poletti A, Celotti F (1996) Metabolism of steroids in the brain: a new insight into the role of $5 \alpha$-reductase and aromatase in brain differentiation and function. J Steroid Biochem Mol Biol 5/6:455-466

67. Gorski RA (1993) Estradiol acts via the estrogen receptor in the sexual differentiation of the rat brain, but what does this complex do? Endocrinology 133:431-432

68. McEwen BS (1991) Non-genomic and genomic effects of steroids on neural activity. Trends Pharmacol Sci 12:141-147

69. McCarthy MM, Schlenker EH, Pfaff DW (1993) Enduring consequences of neonatal treatment with antisense oligonucleotides to 
estrogen receptor messenger ribonucleic acid on sexual differentiation of rat brain. Endocrinology 133:433-439

70. Ogawa S, Taylor JA, Lubahn DB, Korach KS, Pfaff DW (1996) Reversal of sex roles in genetic female mice by disruption of estrogen receptor gene. Neuroendocrinol 64:467-470

71. Rissman EF, Early AH, Taylor JA, Korach KS, Lubahn DB (1997) Estrogen receptors are essential for female sexual receptivity. Endocrinology 138:507-510

72. Koch M (1990) Effects of treatment with estradiol and parental experience on the number and distribution of estrogen-binding neurons in the ovariectomized mouse brain. Neuroendocrinol 51:505-514

73. Ogawa S, Olazabal UE, Parhar IS, Pfaff DW (1994) Effects of intrahypothalamic administration of antisense DNA for progesterone receptor mRNA on reproductive behavior and progesterone receptor immunoreactivity in female rat. J Neurosci 14: $1766-1774$

74. Pollio G, Xue P, Zanisi M, Nicolin A, Maggi A (1993) Antisense oligonucleotide blocks progesterone-induced lordosis behavior in ovariectomized rats. Mol Brain Res 19:135-139

75. Mani S, Blaustein JD, Allen JMC. Law SW, O'Malley BW, Clark JH (1994) Inhibition of rat sexual behavior by antisense oligonucleotides to the progesterone receptor. Endocrinology 135: 1409-1414

76. Power RF, Mani SK, Codina J, Conneely OM, O'Malley BW (1991) Dopaminergic and ligand-independent activation of steroid hormone receptors. Science 254:1636-1639

77. Mani S, Allen JMC. Clark JH, Blaustein JD, O'Malley BW (1994) Convergent pathways for steroid horomone-and neurotransmitter-induced rat sexual behavior. Science 265:1246-1249

78. Mani SK, Allen JMC. Lydon JP, Mulac-Jericevic B, Blaustein JD, DeMayo FJ, Conneely O, O'Malley BW (1996) Dopamine requires the unoccupied progesterone receptor to induce sexual behavior in mice. Mol Endocrinol 10:1728-1737

79. MacLean HE, Warne GL, Zajac JD (1995) Defects of androgen receptor function: from sex reversal to motor neuron disease. Mol Cell Endocrinol 112:133-141

80. Wilson JD (1992) Syndromes of androgen resistance. Biol Reprod 46:168-173

81. Hutson JM, Baker M, Terada M, Zhou B, Paxton G (1994) Hormonal control of testicular descent and the cause of cryptorchidism. Reprod Fertil Dev 6:151-156

82. Griffiths AL, Momose Y, Hutson JM (1993) The gubernaculum in adult female, adult male and TFM male mice. Int $\mathrm{J}$ Androl 16:380-384

83. Naik SI, Young S, Charlton HM, Clayton RN (1984) Pituitary gonadotropin-releasing hormone receptor regulation in mice. I. Males. Endocrinology 115:106-113

84. Blackburn WR, Chung KW, Bullock L, Bardin CW (1973) Testicular feminization in the mouse: studies of Leydig cell structure and function. Biol Reprod 9:9-23

85. Murphy L, O'Shaughnessy PJ (1991) Testicular steroidogenesis in the testicular feminized (Tfm) mouse: loss of 17 $\alpha$-hydroxylase activity. J Endocrinol 131:443-449

86. Le Goascogne C, Sananes N, Gouezou M, Balulieu EE, Robel P (1993) Suppressed expression of the cytochrome P450 $17 \alpha$ protein in the testicular feminized $(\mathrm{Tfm})$ mouse testes. J Endocrinol 139:127-130

87. Eddy EM, Washburn TF, Bunch DO, Goulding EH, Gladen BC, Lubahn DB, Korach KS (1996) Targeted disruption of the estrogen receptor gene in male mice causes alteration of spermatogenesis and infertility. Endocrinology 137:4796-4805

88. Donaldson KM, Tong SYC. Washburn T, Lubahn DB, Eddy EM, Hutson JM, Korach KS (1996) Morphometric study of the gubernaculum in male estrogen receptor mutant mice. J Androl 17: 91-95

89. Nitta H, Bunick D, Hess RA, Janulis L, Newton SC, Millette CF, Osawa y, Shizuta Y, Toda K, Bahr J (1993) Germ cells of the mouse testis express P450 aromatase. Endocrinology 132: 1396-1401
90. Meistrich ML, Hughes TJ, Bruce WR (1975) Alterations of epididymal sperm transport and maturation in mice by oestrogen and testosterone. Nature 258:145-147

91. Ohno S, Geller LN, Young Lai EV (1974) Tfm mutation and masculinization versus feminization of the mouse central nervous system. Cell 3:235-242

92. Olsen KL (1979) Induction of male mating behavior in androgen-insensitive (tfm) and normal (King-Holtzman) male rats: effect of testosterone propionate, estradiol benzoate and dihydrotestosterone. Horm Behav 13:66-84

93. Ogawa S, Lubahn DB, Korach KS, Pfaff DW (1997) Behavioral effects of estrogen receptor gene disruption in male mice. Proc Natl Acad Sci USA 94:1476-1481

94. Shughrue PJ, Komm B, Merchenthaler I (1996) The distribution of estrogen receptor- $\beta$ mRNA in the rat hypothalamus. Steroids 61:678-681

95. Albright F, Smith PH, Richardson AM (1941) Postmenopausal osteoporosis. JAMA 116:2465-2474

96. Eriksen EF, Colvard DS, Berg NJ, Graham ML, Mann KG, Spelsberg TC, Riggs BL (1988) Evidence of estrogen receptors in normal human osteoblast-like cells. Science 241:84-86

97. Komm BS, Terpening CM, Benz DJ, Graeme KA, Gallegos A, Korc M, Greene GL, O'Malley BW, Haussler MR (1988) Estrogen binding, receptor mRNA, and biologic response in osteoblast-like osteosarcoma cells. Science 241:81-84

98. Migliaccio S, Davis VL, Gibson MK, Gray TK, Korach KS (1992) Estrogens modulate the responsiveness of osteoblast-like cells (ROS 17/2.8) stably transfected with estrogen receptor. Endocrinology 130:2617-2624

99. Davis VL, Couse JF, Gray TK, Korach KS (1994) Correlation between low levels of estrogen receptors and estrogen responsiveness in two rat osteoblast-like cell lines. J Bone Miner Res 9:983-991

100. Colvard DS, Eriksen EF, Keeting PE, Wilson EM, Lubahn DB, French FS, Riggs BL, Spelsberg TC (1989) Identification of androgen receptors in normal human osteoblastlike cells. Proc Natl Acad Sci USA 86:854-857

101. Turner RT, Riggs BL, Spelsberg TC (1994) Skeletal effects of estrogen. Endocrine Rev 15:275-308

102. Migliaccio S, Newbold RR, Bullock BC, McLachlan JA, Korach KS (1992) Developmental exposure to estrogens induces persistent changes in skeletal tissue. Endocrinology 130:1756-1758

103. Migliaccio S, Newbold RR, Bullock BC, Jefferson WJ, Sutton FGJ. McLachlan JA, Korach KS (1996) Alterations of maternal estrogen levels during gestation affect the skeleton of female offspring. Endocrinology 137:2118-2125

104. Vanderschueren D, Van Herck E, Suiker AMH. Visser WJ, Schot LPC. Chung K, Lucas RS, Einhorn TA, Bouillon R (1993) Bone and mineral metabolism in the androgen-resistant (testicular feminized) male rat. J Bone Miner Res 8:801-809

105. Barrett-Connor E (1994) Heart disease in women. Fertil Steril 62 [Suppl 2]:127S-132S

106. Barrett-Connor E, Bush TL (1991) Estrogen and coronary heart disease in women. JAMA 265:1861-1867

107. Rubanyi GM, Freay AD, Burton G, Lubahn DB, Couse JF, Korach KS (1997) Decreased production of endothelium-derived nitric oxide in the aorta of estrogen receptor deficient mice. J Clin Invest 10:2429-2437

108. Johns A, Freay AD, Fraser W, Korach KS, Rubanyi GM (1996) Disruption of estrogen receptor gene prevents $17 \beta$-estradiol-induced angiogenesis in transgenic mice. Endocrinology 137: $4511-4513$

109. Iafrati MD, Karas RH, Aronovitz M, Kim S, Sullivan TR Jr, Lubahn DB, O'Donnell TF Jr, Korach KS, Mendelsohn ME (1997) Estrogen inhibits the vascular injury response in estrogen receptor-deficient mice. Nat Med 5:545-548

110. Mendelsohn ME, Karas RH (1994) Estrogen and the blood vessel wall. Curr Opin Cardiol 9:619-626

111. Aitken RJ (1997) The extragenomic action of progesterone on human speramatozoa. Hum Reprod 12 [Natl Suppl]:38-42 